\section{The U.S. and Israel}

To the Editors: I have just seen the Mark Bruzonsky piece in the JulyAugust issue entitled "The U.S. and Israel: In the Eye of the Storm." I was quite disturbed to find Mr. Bruzonsky has repeated again, in the portion headed "Lobby Confrontation in Washington," a reference to me which he had included in an earlier article elsewhere and to which I took strong exception....

In his Worldview piece Bruzonsky again attributes to me a very harsh, personal attack on Morris Amitay. He writes that I had "indicated" that Amitay had certain personal qualities, etc. Although he uses the verb "indicated," he then goes on to include that criticism of Amitay in quotation marks, so it is not clear to me now whether he is actually asserting that $I$ used that language. I did not so characterize Mr. Amitay, and I would not, privately or publicly. It is a matter of public record that Amitay and I have had some disagreements on policy and strategy. The Jewish community is not monolithic, and thus there will be occasions when representatives of the community will disagree. But I have the highest regard for Amitay's commitments and effectiveness. I will continue to express differences with him or others when I feel our common interests require a change in policy or tactics, but I hope always to be able to refrain from personal recrimination.

Hyman Bookbinder

Washington Representative

The American Jewish Committee

Washington, D.C.

To the Editors: In the olden days antiSemites used to call a spade a spade: They came out against Jews. Then Soviet Russia invented a camouflage for anti-Semitism: All you have to do is talk against Zionism. The latest variety of this, however, is: Talk against Begin. However, whichever way the tune goes, the motivation remains the same, even if pronounced by writers of Jewish descent.

Your publication has now consistently throughout some issues followed the "knock Begin" variation on this theme. This culminated in Mark Bruzonsky's interview with Joseph Sisco in your June issue ("Mideast Peace: The Best of Chances"). As I had seen the same interview published earlier in the rabidly anti-Israel Arab publication The Middle East, I knew what slant could be expected. 1 give Mr. Sisco credit for his well-known diplomatic skill in evading the extreme anti-Israel bias of the "Interviewer," who consistently tried to put words in favor of PLO into $\mathrm{Mr}$. Sisco's mouth. He has now topped even that exercise with his article "The U.S. and Israel in the Eye of the Storm" in your July-August issue. Now the gloves are off and the article is peppered with such tendentious expressions as "Begin's deceptions, slanders, and irksome charm," "Israeli intransigence," "Begin used the army to savage Southern Lebanon," "Begin, like Carter, faces dwindling support at home," etc.

If it were not known that Mr. Bruzonsky is a spokesman for the discredited Quisling group called "Breira," it would be hard to understand why he is magnifying out of all proportions such phantoms as "Reputable Jewish Leaders" who recommend "unyielding American pressure" on Israel, or alleged "Israel's best friends" who support Israel's "still expanding Peace Now Movement."

However, the intricate and complex problems of the Middle East should not be viewed through the subjective eyes of a partisan agitator, but through the perspective of thorough knowledge of the religious and historic factors influencing the situation there.

The world perspective of Islam is one of militant conquest and expansion. According to Islam, the world is divided into two spheres: The Dar el Islam, reserved for the Moslems, and the Dar el Harb, the sphere of War and Destruction inhabited by all infidels. From the days of Mohamed it has been the most universally accepted doctrine of Moslems that the entire world must be converted into a Dar el Islam. The means for this is Jihad, the Holy War, which is becoming more and more again a central theme in Moslem thinking and writing.

When I visited President Sadat earlier this year in Cairo, he was visibly upset and unnerved when I challenged him on the basis of the above doctrines: How could he pretend to strive toward a peaceful compromise with Israel, if the doctrine of the Jihad prohibits any permanent peace with infidels who seek sovereignty in any part of land over which Moslems claim sovereignty, (Continued on page 58)

\section{WORLDVEW Statement of Purpose}

The purpose of Wortdview is to place public policies, particularty in intemational affairs, under close ethical scrutiny. The Council on Religion and International Affairs, which sponsors the joumal, was founded in 1914 by religious and civic leaders brought together by Andrew Camegie. It was mandated to work toward ending the barbarity of war, to encourage international cooperation, and to promote justice. The Council is independent and nonsectarian. Worldview is an important part of the Council's wide-ranging program in pursuit of these goals.

Worldview is open to diverse viewpoints and encourages dialogue and debate on issues of public significance. It is edited in the belief that large political questions cannot be considered adequately apart from ethical and religious reflection. The opinions expressed in Worldview do not necessarily reflect the positions of the Council. Through Worldview the Council aims to advance the national and international exchange without which our understanding will be dangerously limited.

Philip A. Johnson, Publisher

\section{Editorial Board:}

Hans Morgenthau, Chairman

William J. Barnds

Eugene B. Borowitz

Noel J. Brown.

Jorge Dominguez

James Finn

J. Bryan Hehir

Donald F. McHenry (on leave)

Paul Ramsey

Seymour Siegel

Paul Sigmund

Kenneth W. Thompson

Howard Wriggins (on leave)

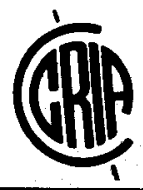

